\title{
The Understanding of Inclusive Education in Kosovo: Legal and Empirical Argumentation
}

Naser Zabeli ${ }^{1}$, Blerta Perolli Shehu ${ }^{\star 2}$ And Jeffrey A. Anderson ${ }^{3}$

$\approx$ The article looks at conceptualisations of inclusive education in the international and Kosovo context, including the factual argumentation and legal representation of the term. The study explores the attitudes of teachers and their understanding of inclusive education, including arguments for and against it, implementation challenges, and perspectives. Interviews were used as a tool to generate information from key informants. The study is qualitative and based on an analysis of the experiences of six in-service teachers. The findings suggest that teachers have a wide knowledge of inclusive education and believe it has only positive effects for children with special needs. They believe that children can achieve more in terms of socialisation and modelling of good behaviours from their peers, but that success in academic achievements is lower because of the limited knowledge of teachers about individualised planning and differentiated teaching, and a lack of institutional support and proper evaluation of each teacher's work.

Keywords: children with special needs, inclusive education, international contexts, Kosovo context, teacher perspectives 


\section{Razumevanje inkluzivnega izobraževanja na Kosovu: pravna in empirična utemeljitev}

Naser Zabeli, Blerta Perolli Shehu in Jeffrey A. Anderson

$\propto$ Članek obravnava konceptualizacije inkluzivnega izobraževanja v mednarodnem okolju in na Kosovem ter dejansko in pravno utemeljuje koncept. Raziskava preučuje odnos učiteljev do inkluzivnega izobraževanja in njihovo razumevanje tega področja ter navaja argumente za inkluzivno izobraževanje in proti njemu, izzive pri njegovem izvajanju in obete za prihodnost. Podatke smo pridobili z intervjuji ključnih oseb. Kvalitativna raziskava je temeljila na analizi izkušenj šestih učiteljev. Ugotovitve so pokazale, da učitelji veliko vedo o inkluzivnem izobraževanju, za katero verjamejo, da v celoti pozitivno učinkuje na otroke s posebnimi potrebami. Po njihovem mnenju so lahko otroci tako uspešnejši od njihovih vrstnikov na področju socializacije in usvojitve primernega vedenja, vendar pa je njihov učni uspeh slabši zaradi omejenega znanja učiteljev o individualiziranem načrtovanju in diferenciranem poučevanju ter zaradi pomanjkanja institucionalne podpore in ustrezne evalvacije dela posameznega učitelja.

Ključne besede: otroci s posebnimi potrebami, inkluzivno izobraževanje, mednarodni konteksti, kosovski kontekst, perspektive učiteljev 


\section{Introduction}

Inclusion is considered to be "a complex and contested concept, and its manifestations in practice are many and varied" (Lindsay, 2003, p. 3). It is multi-dimensional and difficult to define, as it depends on the context of different countries and is, by its very nature, fluid (Dikeledi, 2013). Inclusion is a multi-dimensional concept that incorporates the assessment of differences and diversities, as well as considerations of human rights, social justice and equal opportunities (Shmid \& Vrhovnik, 2015). The concept for inclusive education originates from the field of special education, which is historically based on a medical model of categorising children and segregating education based on disability, and on the separation of children into special classes (Florian, 2014). The present paper outlines the definition and legal framework of inclusive education, reports on some empirical studies on inclusive education, both internationally and in the Kosovo context, and presents the results of a qualitative study looking at perspectives of Kosovo in-service teachers in understanding inclusive education and its effects.

\section{Theoretical Background}

\section{Inclusive education defined in the international context}

There are a variety of different definitions and conceptualisations of inclusive education in the international context, reflecting the differences in different parts of the world (Florian, 2014). "Inclusive education can be defined as a process, philosophy, and educational practice" (Florian, 2005, p. 96). Similarly, Vislie (2003) defined inclusive education as "a process (rather than state), by which a school attempts to respond to all pupils as individuals" (p. 21). UNESCO (2009) defined inclusive education more as a philosophy built on the issue of basic human rights and the belief that all people are equal and should be respected and valued. Braunsteiner and Lapidus (2015) saw inclusive education as "a fundamental right of all children and adults to fully participate, and contribute in all aspects of life and culture, without restriction or threat of marginalization" (p. 32).

The definitions provided above make it clear that inclusive education is a complex concept defined somewhat differently by different stakeholders. Some refer to education for all, while others refer to respecting diversities or the right to education. Some refer to treating disability, while others acknowledge the challenges of discrimination and categories of marginalisation. Nonetheless, most of the definitions are focused on children with disabilities and 
have a common denominator of human rights and the right to an education (Braunsteiner, 2014; Volpe, 2016). Most of the definitions have limitations, as they are based on one or two predefined elements, mainly "child difficulties" and "child rights", or "values" and "communities" (Winter \& O'Raw, 2010). Ultimately, however, when considering the definition of inclusive education, it is important not to confuse it with "special education" (Stubbs, 2008), particularly as it is implemented in practice.

The definition used in the present article includes elements found in the definition of inclusive education by Booth and Ainscow (2002): inclusive education involves processes of increasing the participation of students in, and reducing their exclusion from, cultures, curricula and communities of local schools (as reported in the Index for Inclusion). Booth and Ainscow (2002) pointed out that inclusive education goes beyond a reference to children with disabilities or special educational needs, encompassing not only respecting children, but also respecting staff; reducing exclusion from culture, curricula and the local community; restructuring school cultures, policies and practices; reducing barriers to learning for all students; active and full participation of everyone, according to their given potential; the establishment of relationships between schools and communities; and overall movement towards an inclusive society through inclusive education.

\section{Inclusive education defined in the Kosovo context}

Looking at the definitions of inclusive education among Kosovar scholars, it is evident that inclusive education has stemmed from special education. As in many other countries, this may explain why Kosovo appears to follow three approaches: special education, education for special needs, and inclusive education (Holst, 2008). Inclusive education underlines support for all children regardless of race, gender, ethnicity, disability or any other difference. While there are very few articles about inclusive education in Kosovo, several definitions have been published. Zabeli (2010) defined inclusive education as education for all, an issue of accepting differences, cooperating and socialising among all children. Zabeli (2010) further stated that inclusive education means more than passive participation: it entails increasing student participation in the curriculum, the school and the community; avoiding exclusion; assessing students without bias; mitigating barriers to the learning process; ensuring the full participation of all students; and ensuring that students are educated in their home school and community (pp. 9-10).

Other definitions found in the Kosovo literature indicate that inclusive education is a philosophy such that "all students with disabilities have the right 
to participate in the education, social, recreational and professional activities of their community together with their peers" (OECD, 2006, p. 175). According to Seba and Ainscow (1996), inclusive education is understood to be the "process by which schools attempt to respond to all pupils as individuals by restructuring curricular organization and provision, and allocating resources to enhance equality of opportunity and access" (p. 9).

Definitions of inclusive education in Kosovo are also based on the definition of UNESCO (2009), which states that inclusive education can be viewed as one aspect of inclusion in society. It is "a process of addressing and responding to the diversity of needs of all children, youth, and adults through increasing participation in learning, cultures and communities, and reducing and eliminating exclusion" (UNESCO, 2009, pp. 8-9). In order to obtain a more comprehensive view of the conceptualisation of inclusive education, both internationally and in the context of Kosovo, one must review the legal definitions and argumentations, as well. The next section focuses on the view of inclusive education from factual arguments and in legal frameworks.

\section{Legal Framework}

\section{International context}

Inclusive education was initially focused mainly on people with disabilities and learning difficulties (Winter \& O'Raw, 2010). In a study related to supporting or countering inclusive educational ideals for children with disabilities, Cole (1999) identified several arguments. First, the consequentialist argument is based on the view that demonstrated outcomes determine the worth of activity. This promotes an empirical approach focusing on efforts to measure the positive and negative outcomes of inclusion policies. Second, the justice argument is linked to equality and the obligation to provide services for people with disabilities. Third, the rights argument recognises the right of people with disabilities for special services. Finally, the needs argument is based on how the needs of people with disabilities should drive the specialisation goals of educational programmes (Cole, 1999). Mitchell (2014) described three factors of basic arguments for the idea of inclusive education: (1) students with special educational needs benefit more in the academic and social perspective, (2) students with special educational needs have the same right to education as all other students, and (3) inclusive education is more cost effective, i.e., it is easier to accommodate children in general education settings than to operate special schools and all that this entails, such as transporting children to school. Similarly, LimbachReich (2015) highlighted three reasons to support inclusive education. "First, 
there is an educational justification, which holds that the requirement for inclusive schools to educate all children together means that schools have to develop ways of teaching that respond to individual differences that benefit all children. Second, was social justification, which holds that inclusive schools are able to change attitudes toward diversity by educating all children together, and form a basis for a just and non-discriminatory society. Third, there is an economic justification, stating that it is less costly to establish and maintain schools that educate all children than to set up a complex system of different types of schools specialising in different groups of children" (UNESCO, 2009, p. 9).

Garcia and Fernandez (2016) hold that "all the European countries promote inclusive education via their legislation" (p. 386), while a number of international United Nations declarations and legal frameworks also support inclusive education. Often based on these international documents, different countries have developed similar legislation and education policies. Therefore, inclusive education is not just an issue of aspirations, but is an obligation of countries to build education systems that include all children regardless of their differences. Indeed, countries today are implementing inclusion policies, moving away from approaches based more on medical-type models, and orienting themselves towards social model frameworks.

\section{Kosovo context}

Inclusive education policies in Kosovo were developed on the basis of special education, and the legal documents drafted by the Kosovo Ministry of Education (MEST) are based on international efforts. Specifically, based on a review of the Kosovo legislation, the principle of inclusive education is incorporated in all of the relevant laws, strategies and curricula governing the functioning of institutions and different educational centres. The MEST policy is aimed at promoting inclusive education, thus ensuring equal education conditions for all. This is also evidenced by the evolution of legislation and other documents, which have transformed previous segregation policies governing special education towards inclusive education (Zabeli, 2014). One of the central documents, the Kosovo Curriculum Framework, promotes inclusive education as the first of its five fundamental principles. Special schools and classes in Kosovo were operational for decades until 2000, when they were transformed into resource centres and classes with the mission of promoting inclusive education. MEST developed corresponding services in municipalities in an effort to support inclusive education by supporting teachers, itinerant (visiting) teachers, assistants and psycho-pedagogical staff, as well as by providing supportive pedagogical policies and ongoing capacity building activities. 


\section{Empirical Studies on Inclusive Education}

\section{International context}

Internationally, debates continue about the effectiveness of inclusive education for children with disabilities who are participating in general education classes. Empirical studies on the achievements of children with special needs who are included in general education point out numerous factors that may influence achievement. Broadly, the literature suggests positive outcomes, but findings are not unequivocal. A literature review by Lindsay (2003) indicated that there are no indications that growing up in segregated and non-segregated settings could lead to better educational outcomes. This finding is not surprising considering the challenges of implementing inclusive education. Lindsay (2007) noted that the literature before the 2000 s did not provide clear patterns. In a review of the literature about the effects of inclusion, Ruijs and Peetsma (2009) focused on the positive, negative and mixed effects on academic achievements and socio-emotional status. In terms of the academic achievements of children with special educational needs, the literature review by Ruijs and Peetsma (2009) found:

- $\quad$ Positive findings (Cole et al., 2004; Jepma, 2003; Karsten et al., 2001; Markussen, 2004; Marston, 1996; Myklebust, 2007; Salend \& Duhaney, 1999).

- $\quad$ Negative findings (Rogers \& Thiery, 2003).

- $\quad$ Mixed and indecisive effects (Huber et al., 2004).

In terms of the socio-emotional development of children with special educational needs, the literature indicated:

- $\quad$ Positive findings (Wiener \& Tadif, 2004)

- $\quad$ Negative findings (Bakker \& Bosman, 2003)

- $\quad$ Mixed and indecisive findings (Jepma, 2003; Mand, 2007; Peetsma, 2001).

These studies were quantitative and longitudinal, although many of them did not use control groups.

According to Ruijs and Peetsma (2009), "the effect of inclusive education on the academic achievement of children with special educational needs seem to be positive. Very few studies reported negative effects of inclusive education on the achievement of children with mild to moderate special educational needs. The studies about socio-emotional effects of inclusive education suggested that children with special educational needs tend to be in less favourable social positions as compared to children without disabilities" (p. 77). 
In addition, studies about the effects of inclusive education on the academic achievement of children without special educational needs found mainly positive results. "Studies on children with more severe special educational needs indicated that children without special educational needs in inclusive classes had fewer prejudices about children with special educational needs" (Ruijs \& Peetsma, 2009, p. 78). These students were found to be more willing to play with students with significant needs and hold a more positive attitude towards this group of young people. Begeny and Martens (2007) concluded that "study participants tended to view inclusive education practices favourably" (p. 89); on the other hand, findings from "experimental studies suggested that educating students either fully or partly outside the general classroom had a positive impact on these students across the majority of dependent measures evaluated" (p. 369). Some findings from German-speaking countries concluded that, through inclusive education, children with learning difficulties showed better academic performance.

Nonetheless, existing research has not confirmed that inclusive education "has a dominant and mainly positive effect for all children with disabilities, with positive effects on both academic outcomes and socio-emotional dimensions, or without negative effects on classmates without disabilities" (LimbachReich, 2015, p. 371); and further, that in order to be successful, inclusive education requires changes in school systems and society. One important conclusion is that policy should not include students first and then hope that the system will change later (Limbach-Reich, 2015). It is possible that the similarities and differences between studies on the effects of inclusive education are more contextual than methodological in nature, and are dependent on education policies, the education system, inclusive education practices, teacher preparation, partnership with the community, leadership, and functional cooperation between all of these aspects and stakeholders (European Agency for Development in Special Needs Education, 2013).

\section{Kosovo context}

In Kosovo, there is no sound research on inclusive education and the few studies that exist were not conducted rigorously. This is a result of several factors, including a lack of funding at all levels, poor working conditions, insufficient access to libraries and international journals, lack of research skills, and lack of good preparation of professionals to conduct individual and group design studies (Leskinen, 2008). On the other hand, many capacity building activities have been undertaken to prepare in-service teachers, and these efforts have contributed to a better understanding of inclusive education and improved 
skill building aimed at working with children with special educational needs. According to Forlin (2013), "to ensure that inclusive educational approaches actually address the needs of learners and that implementation ideas through policy development are manageable and practicable, a proactive systemic approach is needed that is supplemented by local input and involvement" (p. 27). "Policy needs to be firmly embedded in and informed by local research that addresses the specific needs of a region by considering city and rural situations, fiscal constraints, support structures, and the capabilities of those who are to implement it. Indeed, to fully enact an effective inclusive education approach requires appropriate preparation and participation of all stakeholders. This particularly applies to the training of staff at all levels, from system to classroom" (Forlin, 2013, p. 28)

The purpose of the present study was to explore the perspectives of teachers, specifically their understanding of the definition of inclusion, arguments for and against it, implementation challenges, and views about inclusive education. The research was guided by the following research questions:

1. How is inclusive education conceptualised by in-service teachers? How do teachers understand "inclusive education" in the process of transition from special education as a segregated practice?

2. What are the legal/empirical arguments for inclusive education?

3. How do teachers assess the effects of inclusive education?

4. What are the challenges in implementing inclusive education?

\section{Method}

This section describes the methods used to examine the issue, including a description of the sample, the design of the study, and the approaches to data collection and analysis.

Research methodology literature suggests using qualitative approaches in order to better grasp the understanding, experiences and contextual factors of a given situation. Through qualitative approaches, one is able to analyse the perspectives and understanding of teachers, bearing in mind the contextual factors and the uniqueness of the situations being studies (Gay et al., 2006). Moreover, while statistical data may be more reliable, analysing understandings or attitudes can be challenging (Silverman, 2001). As such, the present study aimed to gain a better picture of the situation and deepen the understanding of subjective experiences, rather than testing hypotheses.

The findings were extracted from data collected through document analysis and by exploring teacher understanding. In-depth interviews were 
used to obtain the data, with the aim of gaining a better quality of description and more detailed opinions about the subject matter. The in-depth interviews were analysed using content analysis (Kolbe \& Burnett, 1991). Studies conducted in the past using similar methods were examined in order to support the qualitative design of the present study. Thus, the methodology and instruments in this study can be considered 'typical' when compared other such studies.

\section{Participants}

Due to time restrictions regarding interviewing and data analysis, the use of in-depth interviewing was limited to six teachers. Using a convenient approach to sampling, the study targeted teachers with diverse work experience and professional preparation, and from diverse locations. The sample consisted of teachers from all levels of the "pre-university education system" who were working in general education schools and in resource centres. All of the teachers chosen for the study had considerable experience working with children with special needs. They had a good knowledge of the area of special education and inclusive education, and had attended formal education and numerous trainings in the field. The sample consisted of two itinerant teachers working in regular schools, three teachers from resource centres, and one 'supporting teacher' from a regular school.

\section{Data Collection Instrument}

In-depth interviews were used to generate information from the key informants. The following questions made up the core of the interview:

1. How do you define/understand inclusive education?

2. Which laws and pedagogical documents support you in implementing inclusive education? To what extent are these laws harmonised to allow for the implementation of inclusive education?

3. What are the effects of inclusive education for children with special educational needs?

4. What are the positive/negative effects of inclusive education in general?

5. What are the challenges in implementing inclusive education? What is your perspective in terms of the Kosovo context?

The interviews were all recorded and varied in length from 1 hour to 1 hour and 45 minutes. They were conducted in an informal, conversational style and all of the questions were open-ended. 


\section{Research design}

Qualitative research methodology suggests that the experience of researchers is important, especially with regard to the context, particularly contextual factors. Every study is therefore unique in this sense. According to qualitative approaches, the researcher generates new hypotheses and theories based on collected data (Lichtman, 2006). In order to develop theories rather than generalise conclusions, the data were therefore gathered through in-depth interviews with teachers. This method provides an opportunity for free expression and deeper questioning of the topic (Cohen \& Manion, 1990), and reflects an explanatory and exploratory research study (Matthews \& Ross, 2010). Moreover, content analysis allowed the researchers to compare basic concepts identified in the literature with the perspectives of teachers interviewed in this study, in order to determine similarities and differences and then code relevant data for future use, according to the grounded theory approach (Matthews \& Ross, 2010).

\section{Data analysis}

The study was designed so that the themes were not imposed by the research, but rather generated by the interviewees. The interviews were recorded and transcribed, and then analysed, coded and categorised based on elements found in the responses and compared to the literature. This information was interpreted and conclusions were derived via rigorous detailed analyses.

\section{Results}

\section{Understanding inclusive education from the teacher's perspectives}

(rights based on legislation)

According to the study participants, inclusive education involves "equal participation" of everyone, and the implementation of inclusive education requires that the curricula is adapted for all students. Inclusive education implies the inclusion of students with special needs in a supportive environment that provides equal opportunities. Inclusive education is understood as a process that implies the inclusion of all children in education guaranteed by the right to education regulated and supported by necessary legislation and policies.

"Inclusive education is a broad term that implies the inclusion of all children in the learning process - not only children with disabilities, but all children - by adapting the learning outcomes to psycho-physical skills and not just physical or social involvement." (Itinerant Teacher) 
"Inclusive education is education for all in a school that guarantees the right to all children regardless of age, gender, race and ethnicity. Education in the nearest school, regardless of physical injuries, socioeconomic aspects, together with other children." (Teacher, grade 1-5)

On the other hand, the findings indicated that, among the teachers who did not have any - or had very little - formal (and informal) training about inclusive education, many respondents did not understand the essence of inclusive education. Some of this group viewed inclusive education very superficially, more like "physical integration" or passive inclusion in classes based solely on the right to education, rather than on the student's ability to attain academic achievement or social development. The inclusion of students in regular classes was viewed with more scepticism by this group of teachers. The respondents reported being reluctant to include and work with children with various difficulties. Working with students with special needs was considered more a "humane action" than part of professional responsibility. Resource centre teachers appear to possess good knowledge and experience compared to teachers in regular schools, who seemed to lack knowledge. The latter group considered students with special needs only in terms of physical presence and to some extent in terms of social integration, but not as children who can be supported to realise their academic potential.

"They only consider them as part of the classroom where they can play with others without paying attention to the fact that they need to and can also develop their intellectual potentials. They understand it more as physical and social involvement, but not academic." (Itinerant Teacher)

"Colleagues at the resource centre are hesitant, very hesitant about regular schools. They (regular schools) only think about physical integration, but active involvement is hard." (Chemistry Teacher Grades 6-12)

While teachers seem to have a clear understanding of the legal basis and administrative instructions that regulate the issue of the inclusion of children with disabilities in education, the respondents consider it a very challenging task, exacerbated by the fact that teachers may not have institutional support, such as assistants or access to expertise:

"Teachers still do not understand that working with children with special needs is a constituent part of their work, but they do it more out of 
humane reasons. It is very challenging; the large number of pupils in the class doesn't allow for more quality work. They need professional support within the school." (Itinerant Teacher)

Indeed, all of the participants pointed out that inclusive education is perceived by teachers more as a "humane action" rather than a professional responsibility. When asked why, they referenced Kosovo culture, where support for people in need (because of a lack of institutionalised support) is considered a moral obligation. This seems to be reflected in working with children with special needs, as well. Supporting others is a moral value embedded in Kosovo culture, and moral norms appear to serve as a substitution for the lack of institutional laws and the lack of professional obligation. In this context, it often happens that teachers say, "I work with children with special needs because I feel it is our moral obligation". Teachers consider it very difficult to work with children who have intellectual or cognitive disabilities, hearing impairments, communication difficulties, or emotional and behavioural disorders, and say that these learners have a place in special classes or schools, but not in regular classrooms or schools:

"Teachers of other schools, regular schools, are very afraid of having a child with special needs in the classroom, saying they don't know what to do with them, and their place is in special schools, special classes. Teachers in resource centres see it as more reasonable for regular school education." (Teacher Grades 1-5)

The respondents noted that laws and pedagogical documentation are grounded in and aligned with international conventions on child rights and other international documents, but there are major shortcomings in their effective implementation. Laws and other documents are adequate and trainings have provided teachers knowledge about them. Likewise, the interviewees said that school principals are not very knowledgeable, or at least are only formally knowledgeable. Teachers know that the law provides for inclusive education, but also consider it a "loss of time" to work with students who have significant learning difficulties. This perception was more indicative of subject teachers from grade six onwards, and was viewed as deriving from the lack of monitoring of teachers, who may be unaware of their performance and motivation for the work undertaken.

"The law on pre-university education provides support for inclusion and is in accordance with world documents. Laws and pedagogical 
documents are good, but the problem lies in implementation." (Itinerant Teacher)

"Teachers do not have enough support from the state. There is a lack motivation of teachers." (Itinerant Teacher)

The respondents indicated that teachers have knowledge about the legal rights of pupils to education and that this makes sense, but they view implementation as difficult. Teachers believe that they do not have adequate institutional support or the support of school leaders to implement inclusive education.

\section{Effects of inclusion on children with special needs}

All of the teachers reported that inclusion has no negative effects. They reported positive impacts in the development of social skills, cooperation between students, friendly relationships, and generally good attitudes. On the other hand, the responses indicated that there is also a perception that children have higher academic achievement in special classes/resource centres. The teachers believe that academic aptitudes are lower in inclusive classes, while social skills improve more in regular classes. This is because students socialise more, learn positive behaviours and generally find it easier to model positive behaviours. Positive values of inclusive education of students in regular classes could be found in all of the teachers' interviews, particularly in regard to social development.

"Positive impacts on emotional and social aspects are noted, good cooperation with regular class students, friendly relationships, modelling good behaviour and feeling equal. Even in academic achievements they develop well. I do not see anything negative. Academic achievements are perhaps better in resource centres, as the learning content is taught faster because the teachers are more specifically trained." (Chemistry Teacher Class 6-12)

"The positive aspect is their socialisation; achievements in learning are more evident in resource centres, needs are better identified and are properly evaluated and better planned." (Itinerant Teacher)

"The positive aspect is that the student is educated in the nearest school together with other children; this positively influences their socioemotional development. If the student with special needs in the regular 
classroom has a dedicated teacher, a professional assistant, then the achievements are better in every respect. Children with minor impairments learn more in regular classes, while children with severe impairments learn more in resource centres." (Teacher Grades 1-5)

\section{Challenges and prospects of implementing inclusive education}

The implementation of inclusive education as a philosophy, and even more as a strategy, is seen as a major challenge for the future. The immediate concerns are the large number of children per classroom, the lack of adequate training, the lack of classroom assistants, the lack of access to expertise, the poor physical infrastructure, and the limitations of teacher monitoring and performance assessment. Individually and together, these elements pose a challenge to the future of inclusive education. Teachers consider that inclusive education will bring about positive change; however, this will take time.

"Inclusive education will require a lot of time; we need to change the culture at the school level, the way of managing schools. It is still thought that a student with special needs 'breaks' the class structure; it is still thought that the average grade of the class is the most important thing, and that a good teacher is one who has a high class average." (Itinerant teacher)

"There is no dilemma regarding the need for inclusive education; however, there is a need for wider support for teachers and preparation of systems to support students better." (Itinerant teacher)

In general, teachers are in favour of inclusive education and are realistically optimistic for the future of inclusive education; however, a significant amount of change is needed to achieve this goal.

\section{Discussion}

The results of the present study can inform current and ongoing efforts in Kosovo to move towards more effective inclusive practices in its primary and secondary schools. The scholarly literature in this area provides a variety of definitions and interpretations. Interestingly, while numerous definitions of inclusion exist among educators and policymakers (both within and between nations), the term also incorporates a variety of contradictory ideologies and practices (Alur \& Timmons, 2009). The definitions provided by the teachers in 
this study are similar to those of various scholars who publish in this area. We found that they were largely based on existing legal arguments, the right to education, and the right to access to the nearest school, regardless of disabilities or differences (Braunsteiner \& Lapidus, 2014; Mitchell, 2005, 2014; Thomas, 1997; Volpe, 2016). We also found that the teachers involved in the study understood the essence of inclusive education and are aligned with current thinking about the moral basis of inclusion.

Positive effects of inclusive education were clearly indicated by the teachers. This was similar to our analyses of literature and empirical studies, which tend to suggest that inclusive education has more advantages when compared to segregation, both in terms of academic as well as social benefits. One interesting finding in this study is the fact that achievement is seen to be greater in terms of skills development rather than academic achievement. While different studies have shown that academic achievements are greater than social outcomes, the present research suggests the opposite. However, we note that this finding is consistent with Ruijs and Peetsma (2009), who found that reaching conclusions on the effects of inclusive education is impossible. In the Kosovo context, teachers have traditionally used one lesson plan for all students in a given class, and the teaching is still largely oriented towards average students, ignoring individual students' needs. There is no differentiated instruction. As such, in classrooms where planning ignores the strengths and needs of individuals, students with special needs are less likely to benefit academically, although these students may still be benefiting socially.

In the pedagogical tradition and in Kosovar culture, people with special needs are more often perceived as "cases in need", as people who need to be assisted in order to live and be accepted in society. Similarly, teachers consider work with children with special needs as philanthropic work (Lily Family School of Philanthropy, 2014) instead of as part of their professional responsibility. In this context, teachers who lack knowledge and experience in working with children with special needs may consider this work more like a volunteer job rather than a professional responsibility that is an integral part of their job. Other studies have also found that some teachers consider working with children with special needs as a humane and moral act (Freire, 2014; Mohan \& Subashini, 2016).

The challenges to the implementation of inclusive education in Kosovo are more of a practical nature, related to physical and logistical infrastructure. The future of inclusive education is seen as feasible, but it also requires time and significant support to increase the level of inclusive culture in general. "Schools and school districts need to provide support at the administrative level and 
classroom level, and provide time for training, and an ongoing commitment from the government" (Hicks-Monroe, 2011, p. 68). Inclusive education requires cohesion among administrators, parents and students, and sensitisation to the needs of students with disabilities (Hunter-Johnson et al., 2014). Given current socio-political contexts and the overall importance of inclusive education, we suggest that sustained work over the next 15 to 20 years will be necessary (Cigman, 2007; Norwich, 2007).

\section{Conclusion}

In conclusion, the present study uncovered rather clear answers to its driving research questions. What emerged is that trained special educators understand inclusion in ways that are similar to those found in the published literature. On the other hand, this shared understanding is not seen in regular class teachers and those working in resource centres. Furthermore, this was regardless of the practitioner's prior education, suggesting that practical work with children with special needs in inclusive settings may influence how teachers understand inclusive education. This work has implications for both teacher education programmes and capacity building efforts. Specifically, we recommend that practical training is needed in addition to more theoretical approaches to understanding inclusion. However, we note that this study focused on the experiences of only six teachers. As such, we recommend more rigorous studies be conducted to explore the relationship between practical/direct work with children in inclusive settings and how practitioners understand inclusion.

Finally, we were very encouraged that all of the teachers in this study perceived inclusion to have only positive effects on students with special needs. Respondents perceived that children can achieve more in terms of socialisation, are more socially accepted, and learn appropriate behaviours from their peers through modelling; however, academic achievement was not viewed with similar optimism. Although there are studies suggesting both social and academic gains for students with special needs who are served in an inclusive setting, we recommend that future research, both quantitative and qualitative, be conducted in the broader Kosovo context. Such studies should explore how different instructional methodologies, techniques and innovations are associated with improved academic achievement in inclusive classrooms in Kosovo. The participants in the present study all agree that effective cooperation between relevant actors, along with sustainable institutional support for teachers, parents and children, could make inclusive education successful in Kosovo. This indicates the need to develop community programmes that strengthen 
collaboration between schools, families and children, as well as initiatives that bring together policymakers and civil institutions, such as health, child welfare and mental health institutions, to build and increase institutional support for the implementation of inclusive education throughout Kosovo.

In addition to the small sample size, a primary limitation of this study is the relatively short period that inclusive education has been considered in Kosovo. It is a new state, only twelve years old, and its educational infrastructure is also relatively new. The level of awareness of inclusion is generally low, and successful experience of actually implementing inclusion is even lower. Another limitation is that this particular study was based on the experiences of teachers who have adequate preservice and in-service training in the field of education, while the itinerant teachers included in the study also have a good knowledge of the understanding of other teachers regarding inclusive education. The researchers plan to continue the efforts initiated with this study by employing a more quantitative approach including a larger number of participants. This next study will examine variables related to teacher experience, quality of work, professional training, etc. A third study is also being planned that will examine the experiences of children and parents with inclusive education in Kosovo. We know that the results of studies like these are essential to identify the strengths and gaps in the Kosovar education system and to encourage the implementation of effective inclusive education. Findings from this and future studies will help shape teacher education and training programmes, as well as informing the policies and practices of the implementation of inclusive education in Kosovo.

\section{References}

Alur, M., \& Timmons, V. (2009). Inclusive education across cultures: Crossing boundaries, sharing ideas. Sage Publications India.

Begeny, J. C., \& Martens, B. K. (2007). Inclusionary education in Italy: A literature review and call for more empirical research. Journal of Remedial and Special Education, 28(2), 80-94.

Booth, T., \& Ainscow, M. (2002). Index for inclusion. Centre for Studies on Inclusive Education.

Braunsteiner, M., \& Mariano-Lapidus, S. (2014). A perspective of inclusion: Challenges for the future. Global Education Review, 1(1), 32-43. https://files.eric.ed.gov/fulltext/EJ1055217.pdf

Cigman, R. (2007). A question of universality: Inclusive education and the principle of respect.

Journal of Philosophy of Education, 41(4), 775-793.

Cohen, L., \& Manion, L. (1990). Research methods in education (third edition). Routledge.

Cole, P. (1999). The structure of arguments used support or oppose inclusion for students with disabilities. Journal of Intellectual \& Developmental Disability, 24(3), 215-225. 
Dikeledi, M. (2013). Theory and practice in the implementation of the inclusive education policy: Reflections through Freire and Bronfenbrenner's Lenses. Mediterranean Journal of Social Sciences, 4(13), 163-169.

European Agency for Development in Special Needs Education (2013). Organisation of provision to support inclusive education - literature review. EADSNE. https://www.european-agency.org/ sites/default/files/organisation-of-provision-to-support-inclusive-education-2013-literature-review_ Organisation-of-Provision-Literature-Review.pdf

Florian, L. (2005). 'Inclusion', 'special needs' and the search for new understandings. Support for Learning, 20(2), 96-98.

Florian, L. (2014). What counts as evidence of inclusive education? European Journal of Special Needs of Education, 29(3), 286-294.

Forlin, Ch. (2013). Changing paradigms and future directions for implementing inclusive education in developing countries. Asian Journal of Inclusive Education, 1(2), 19-31.

Freire, P. (2014). Pedagogy of the oppressed (3oth anniversary edition). Bloomsbury.

García, M. B., \& Fernández, M. T. (2016). The inclusive education in Europe. Universal Journal of Educational Research, 4(2), 383-391.

Gay, L., Mills, G., \& Airasian, P. (2006). Educational research: Competencies for analysis and applications. Pearson Education.

Hicks-Monroe, Sh. L. (2011). A review of research on the educational benefits of the inclusive model of education for special education students. Journal of the American Academy of Special Education Professionals, Win 2011, 61-69.

Holst, J. (2008). Development of inclusive education in Kosovo - challenges and outcomes. Finnish Support to the Development of Education in Kosovo.

Johnson, B., \& Christensen, L. (2008). Educational research: Quantitative, qualitative and mixed approaches. Sage Publications.

Kolbe, R. H., \& Burnett, M. S. (1991). Content-analysis research: An examination of applications with directives for improving research reliability and objectivity. Journal of Consumer Research, 18(2), 243-250.

Kosovo Assembly. (2011). Law on pre-university education in the republic of Kosovo No.04/L -032. https://www.kuvendikosoves.org/common/docs/ligjet/Law\%20on\%2opreuniversity\%2oeducation. pdf

Kosovo Assembly. (2011). Law on higher education in the Republic of Kosovo No.04/L-037. https:// masht.rks-gov.net/uploads/2015/06/o2-ligji-per-arsimin-e-larte-anglisht.pdf

Leskinen, M. (2008). Research and development: The role of research in development of education in Kosovo. Finnish Support to the Development of Education in Kosovo.

Lilly Family School of Philanthropy (2014). Understanding philanthropy education K-12: A typology. Indiana University.

Lindsay, G. (2003). Inclusive education: A critical perspective. British Journal of Special Education, $30(1), 3-15$. 
Lindsay, G. (2007). Educational psychology and the effectiveness of inclusive education mainstreaming. British Journal of Educational Psychology, 77(1), 1-24.

Lichtman, M. (2006). Qualitative research in education: A user's guide. Sage Publications. Ministry of Education, Science and Technology. (2010). Kosovo education strategic plan 2011-2016. http://www.herdata.org/public/KESP_2011_2016.pdf Ministry of Education, Science and Technology. (2010). Strategic plan for organizing inclusive education for children with special educational needs in pre-university education In Kosovo $2010-2015$. https://masht.rks-gov.net/uploads/2015/o6/strategic-plan-for-organizing-inclusive-education-forchildren-with-special-educational-needs-in-pre-university-education-2010-2015.pdf Ministry of Education, Science and Technology. (2011). Curriculum framework for pre-university education. http://www.ibe.unesco.org/curricula/kosovo/kv_alfw_2011_eng.pdf Ministry of Education, Science and Technology. (2012). Core curriculum for pre-primary grade and primary education. https://masht.rks-gov.net/uploads/2015/10/core-curriculum-for-pre-primarygrade-and-primary-education-in-kosovo.pdf Ministry of Education, Science and Technology. (2016). Kosovo education strategic plan 2017-2021. http://www.kryeministri-ks.net/repository/docs/KOSOVO_EDUCATION_STRATEGIC_PLAN.pdf Mitchell, D. (2005). Contextualising inclusive education evaluating old and new international perspectives. Routledge

Mitchell, D. (2014). What really works in special and inclusive education - Using evidence-based teaching strategies (2nd ed.). Routledge.

Mohan, S. A., \& Subashini, A. E., (2016). Role of teachers in inculcating values among students. National Conference on Value Education through Teacher Education, 1(2), 23-28.

Monroe-Hicks, L. Sh. (2011). A review of research on the educational benefits of the inclusive model of education for special education students. Journal of AASEP, Win 2011, 61-69. https://files.eric. ed.gov/fulltext/EJ1136899.pdf

OECD. (2006). Education policies for students at risk and those with disabilities in South Eastern Europe. https://www.oecd-ilibrary.org/docserver/9789264036161-en.pdf? expires $=1585222646 \&$ id=id\& accname $=$ guest $\&$ checksum $=88$ A9F1DA6119A30oACoB15Fo7E79oFE6

Limbach- Reich, A. (2015). Reviewing the evidence on educational inclusion of students with disabilities: Differentiating ideology from evidence. International Journal of Child, Youth and Family Studies, 6(3), 358-378.

Ruijs, N. M., \& Peetsma, T. T. D. (2009). Effects of inclusion on students with and without special educational needs reviewed. Educational Research Review, 4(2), 67-79.

Sebba, J., \& Ainscow, M. (1996). International developments in inclusive schooling: Mapping the issues. Cambridge Journal of Education, 26(1), 5-18.

Silverman, D. (2001). Interpreting qualitative data: Methods for analysing talk, text and interaction (2nd ed.). Sage.

Thomas, G. (2003). Inclusive schools for an inclusive society. https://onlinelibrary.wiley.com/doi/ $\mathrm{pdf} / 10.1111 / 1467-8527.00024$ 
UNESCO. (2009). Policy Guidelines on Inclusion in Education. United Nations: UN Educational, Scientific and Cultural Organization. https://unesdoc.unesco.org/ark:/48223/pfoooo177849 Vislie, L. (2003). From integration to inclusion: focusing global trends and changes in the western European societies. European Journal of Special Needs Education, 18(1), 17-35.

Volpe, V. D. (2016). What about inclusive education and ICT in Italy: A scoping study. European Scientific Journal, 12(25), 26-36.

Winter, E., \& O'Raw, P. (2010). Literature review of principles and practices relating to inclusive education for children with special educational needs. National Council for Special Education: ICEP. https://ncse.ie/wp-content/uploads/2014/10/NCSE_Inclusion.pdf

Zabeli, N. (2010). Edukimi inkluziv [Inclusive Education]. WUS - Austria \& Universiteti i Prishtinës. Zabeli, N., \& Behluli, L. (2014). Index for inclusion - Facts and opinions. Save the Children.

\section{Biographical note}

NASER ZABeLI, PhD, is an associate professor in the field of Inclusive Education and Effective Learning and Teaching in the Department of Pedagogy at the Faculty of Education, University of Pristina in Kosovo. His research interests are mainly in the inclusive education and contemporary teaching.

Blerta Perolli-Shehu, PhD, is teaching assistant at the Faculty of Education, University of Prishtina covering subjects of child development, inclusive education and research methodologies. Her research interests are mainly on child development (typical and atypical), early childhood development, social competence development in marginalized children, and inclusive education.

JefFrey A. Anderson, $\mathrm{PhD}$ is professor in the Indiana University School of Education. He teaches topics in Special Education research and Curriculum and Instruction. His research interests are mainly Special/Inclusive Education and research topics on students with emotional and behavioral disabilities and students with learning disabilities. 